Modern Heroism 



\section{MODERN HEROISM}

Essays on D. H. Lawrence, William Empson, \& J. R. R. Tolkien

\section{Roger Sale}


University of California Press

Berkeley and Los Angeles

University of California Press, Ltd.

London, England

ISBN: 0-520-02208-4

Library of Congress Catalog Card Number: 73-186106

Copyright (C) 1973 by The Regents of the University of California Second printing, 1975

Printed in the United States of America 
for Dorothy 
